\title{
Using a brief family-based DBT adjunct with standard FBT in the treatment of Anorexia Nervosa
}

\author{
Annaleise Robertson*, Colleen Alford, Andrew Wallis, Jane Miskovic-Wheatley \\ From 2015 ANZAED Conference: Riding the Waves to Recovery \\ Surfers Paradise, Australia. 21-22 August 2015
}

The outpatient program at The Children's Hospital at Westmead (CHW) Eating Disorder Service uses Maudsley family-based therapy (FBT) as the main therapeutic model. For families that experience a high level of distress, avoidance of conflict or emotional expression, or if the young person is engaging in high risk behaviour like self-harm or suicide attempts, the parents ability and confidence to persist with refeeding is often severely undermined. In practice this reduces the efficacy of standard FBT, leading to poor engagement, multiple inpatient admissions, longer treatment and drop-out. The team at $\mathrm{CHW}$ are trialling a brief 6 session adjunct based on the core principles of Dialectical Behaviour Therapy (DBT), teaching the young person, their parents and siblings basic skills to engage in mindfulness, distress tolerance, emotion regulation and effective interpersonal relationships. These DBT skills have been adapted to a framework that maintains the core principles and structure of FBT. This oral presentation will discuss the family-based DBT adjunct and its implementation, including session outlines and a case example. Initial data on its effectiveness for patient and parent experience may also be discussed.

Published: 23 November 2015

doi:10.1186/2050-2974-3-S1-039

Cite this article as: Robertson et al:: Using a brief family-based DBT

adjunct with standard FBT in the treatment of Anorexia Nervosa.

Journal of Eating Disorders 2015 3(Suppl 1):O39.
Submit your next manuscript to BioMed Central and take full advantage of:

- Convenient online submission

- Thorough peer review

- No space constraints or color figure charges

- Immediate publication on acceptance

- Inclusion in PubMed, CAS, Scopus and Google Scholar

- Research which is freely available for redistribution
() Biomed Central

* Correspondence: annaleise.robertson@health.nsw.gov.au

The Children's Hospital at Westmead, Australia

(c) 2015 Robertson et al. This is an Open Access article distributed under the terms of the Creative Commons Attribution License 